\title{
15. SITE 632: PLIOCENE-PLEISTOCENE SEDIMENTATION CYCLES IN A BAHAMIAN BASIN ${ }^{1}$
}

\author{
John J. G. Reymer, ${ }^{2}$ Wolfgang Schlager, ${ }^{2}$ and André W. Droxler ${ }^{3}$
}

\begin{abstract}
We established a high-resolution stratigraphy in the Pliocene-Pleistocene of Site 632 (Exuma Sound, Bahamas) and used it to compare glacial and interglacial sedimentation rates of turbidites and periplatform ooze. This stratigraphy is based on downhole variation of aragonite content in periplatform ooze, on nannofossil zonation, and on lithologic correlation with nearby Site 633, where aragonite stratigraphy was complemented with oxygen-isotope curves and magnetostratigraphy.

The top $33.5 \mathrm{~m}$ at Site 632 presents a complete record of glacial cycles down to isotope Stage 24. Sedimentation is characterized by high-stand shedding (i.e., high sedimentation rates during interglacial high stands of sea level and low rates during glacial low stands). Turbidite contributions and sedimentation rates of periplatform ooze vary in unison. This proves that the reduced sedimentation rates of glacial intervals are caused partly by reduction of sediment input during glacial low stands when banks are exposed and produce little sediment. Intensified dissolution during glacials is not solely responsible for the difference between glacial and interglacial sedimentation rates. A trend of decreasing sedimentation is superimposed on the glacial/interglacial rhythm. This trend may reflect filling of the old axial valley (where Site 632 is located) and gradual deepening of a new axial valley that diverts sediment into nearby Exuma Canyon.

In the interval from 33.5 to 84 meters below seafloor (mbsf) (lower Pleistocene and upper Pliocene) erosion from turbidity currents and poor recovery resulted in a fragmentary record that inhibits detailed glacial/interglacial comparisons. However, the overall character of the aragonite curve is clearly visible. This curve is similar to the global oxygenisotope curve, especially regarding the decreased amplitude downhole and the disappearance of 100,000-yr cycles.
\end{abstract}

\section{INTRODUCTION}

During the past 15 years, sediments on the flanks of the Bahama Banks ("periplatform deposits," Schlager and James, 1978), emerged as a crucial source of information for platform history, especially the response of platforms to sea-level fluctuations. Periplatform sediments can provide this information because they are a mixture of bank-derived material recording events on the platform and pelagic sediment carrying oceanic environmental signals.

Leg 101 provided the first opportunity to examine a periplatform record older than latest Pleistocene. Site 632 is unique among Leg 101 sites because it is located on the flat basin floor of one of the major Bahamian basins, Exuma Sound. The high declivity of platform slopes leads to effective bypassing by turbidity currents. Consequently, mud and ooze accumulate on these slopes, whereas a rhythmic succession of graded beds and ooze is deposited on the basin floors. Site 633, studied by Droxler et al. (this volume) provided an ideal setting for documenting the stratigraphy and depositional history of periplatform ooze and mud. On the other hand, Site 632 afforded us an opportunity to examine an ooze-turbidite sequence with regard to glacial/interglacial sedimentation cycles.

In the Tongue of the Ocean basin, Droxler and Schlager (1985) found that turbidites are more abundant during interglacial high stands of sea level. This agrees with a well-known trend toward higher bulk-sedimentation rates in interglacial periplatform deposits, compared with glacial periplatform deposits (Lynts et al., 1973; Mullins, 1983; Droxler, 1984). The concentration of turbidites in high-stand deposits has important implications for the more distant geologic past. Statistical analysis of turbidite

\footnotetext{
${ }^{1}$ Austin, J. A., Jr., Schlager, W., et al., 1988. Proc. ODP, Sci. Results, 101: College Station, TX (Ocean Drilling Program).

2 Institute for Earth Sciences, Free University, P.O. Box 7161, 1007 MC Amsterdam, The Netherlands.

${ }^{3}$ Rice University, P.O. Box 1892, Houston, TX 77251.
}

frequency may provide a way to identify short sea-level cycles even where we cannot control time when calculating sedimentation rates with a resolution of tens of thousands of years. Furthermore, turbidite deposition, unlike ooze deposition, is little affected by seafloor dissolution. Therefore, glacial/interglacial differences in turbidite deposition should reflect differences in sediment input from the banks.

We had several goals in this study: first, to extend the variation of aragonite concentration in a basin setting beyond the latest Pleistocene; second, to compare glacial and interglacial sedimentation rates; and finally, to log the frequency and thickness of turbidites with regard to the glacial rhythm of sea level.

\section{METHODS}

\section{Core Material and Sampling}

An 83.8-m-long sequence of hydraulic piston cores from Hole 632A was the basis for this study. This hole was drilled in Exuma Sound, Bahamas, at $23^{\circ} 50.44^{\prime} \mathrm{N}, 75^{\circ} 26.13^{\prime} \mathrm{W}$, in a water depth of $1996 \mathrm{~m}$ (Fig. 1) to a total depth of 141.0 mbsf. Recovery in the interval from 0 to 93.9 mbsf was $73.4 \%$ (Austin, Schlager, et al., 1986). Our detailed stratigraphy is based only on perennial sediment. Identification of turbidites and debris flows was based mainly on shipboard core descriptions, although we also used core photographs. We used the criteria described by Droxler and Schlager (1985) for identifying turbidite layers and debris flows. Turbidites and debris flows were excluded from subsequent sampling as much as possible. Samples were recovered at $10-\mathrm{cm}$ intervals. In cores with turbidites or debris flows, spacing was adjusted to sample carefully the core beneath the lower, often erosive, boundary of a layer. When above a turbidite or debris flow, a sample was recovered well above the gradual upper boundary to avoid the mixing zone between the fine tail of the turbidite or debris flow and the perennial sediment. Tails of the turbidites or debris flows commonly were identified by color differences. In all, 376 samples were studied following these procedures.

\section{Carbonate Mineralogy}

The relative proportions of aragonite, calcite, magnesian calcite, and dolomite were quantified by X-ray diffraction. This method is based on the principle that the amount of each mineral is related to the reflection intensity, which in turn is proportional to the peak area in the diffracto- 


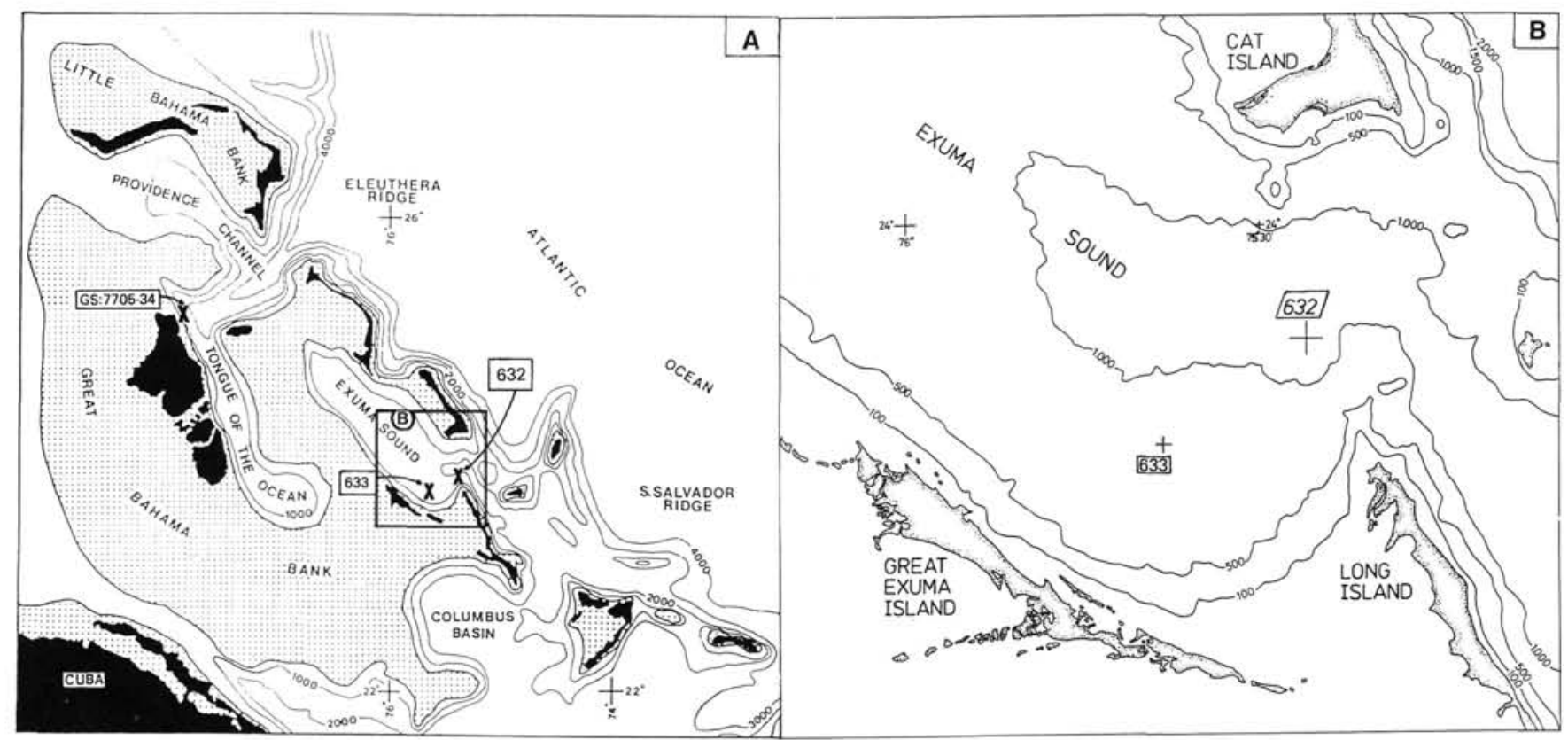

Figure 1. Location map of Sites 632 and 633, Leg 101, Exuma Sound, Bahamas; Core GS:7705-34 (Droxler, 1983), Tongue of the Ocean, Bahamas. A. Contours in meters. Dotted pattern delineates carbonate banks shallower than $190 \mathrm{~m}$ (100 fathoms). Adjacent deep Atlantic east of the 4000 -m contour (modified after Droxler, 1984). B. Contours in fathoms. Dotted pattern indicates islands.

gram (Neumann, 1965). Peak areas were measured by direct integration using a microcomputer attached to an X-ray diffractometer. The analytical procedure was as follows:

1. Each sample was dried at $50^{\circ} \mathrm{C}$, ground for $75 \mathrm{~s}$ in an automatic agate mortar, dry-sieved for the fraction less than $62 \mu \mathrm{m}$, and, finally, packed with a spatula and a glass plate into a brass sample holder. According to Milliman (1974), this sample preparation minimizes the effect of particle size and different grinding times.

2. Samples then were analyzed at the Dutch Institute for Sea Research (NIOZ) by X-ray diffraction using a Philips X-ray (PW 1050/25) diffractometer having self-designed automatic divergence slits and 0.2 $\mathrm{mm}$ receiving slits at $40 \mathrm{kV}$ and $40 \mathrm{~mA}$, using a Kobalt $\mathrm{K}$-alpha tube with $\mathrm{K}$-alpha 1 and $\mathrm{K}$-alpha 2 . A scan was performed from $29.5^{\circ} 2 \theta$ to $36.5^{\circ} 2 \theta$ for each analysis with a scanning speed of $0.5^{\circ} 2 \theta / \mathrm{min}$. At every $0.02^{\circ} 2 \theta$, the reflected quanta were counted for $2 \mathrm{~s}$, digitized, and then integrated to peak area by microcomputer.

3. The percentages of aragonite, dolomite, and calcite, plus magnesian calcite were calculated from the calibration curves in Figure 2. The aragonite/calcite curve was established experimentally from known mixtures of skeletal aragonite (corals) and nannoplankton calcite. The dolomite/calcite curve was taken from Milliman (1974); calcite and magnesian calcites were split following Milliman's technique (1974). The computer program used to analyze the diffraction results (1) determined the background separately from each sample, (2) smoothed the data, (3) determined the peak positions, (4) summed up the reflection quanta over the peak area, (5) calculated peak ratios using these calibration curves, and then (6) produced the relative percentages of the different carbonate minerals.

Samples measured by Droxler et al. (this volume) and for this study indicate that the analyses differ by a mean of $7.7 \%$ for aragonite, $2.5 \%$ for calcite, $7.6 \%$ for magnesian calcite, and $0.8 \%$ for dolomite. Occasional higher discrepancies (up to $8.8 \%, 4.7 \%, 10.4 \%$ and $1.7 \%$ for aragonite, calcite, magnesian calcite, and dolomite, respectively) are attributed to differences in peak resolution. The analytical setup used here provides significantly better resolution of the different calcite peaks than that used by Droxler (1984). Consequently, the low concentrations of magnesian calcite we found in our analyses sometimes were not detected by Droxler (1984) and counted as low magnesian calcite, significantly changing the percentages of the two minerals from those shown here. Fortunately, these discrepancies do not affect the aragonite curve and its use as a correlation tool. In this respect results of Droxler (1984) and of this study agree well.

\section{Quartz}

The variation of quartz content also was obtained by X-ray diffraction, but peak-area estimation was replaced by peak-height analysis. The exact position of the quartz peak was determined separately for each sample and the corresponding peak-height value registered. Subsequently, the specific background value of each sample was subtracted from its raw peak height. A plot of true peak heights vs. depth is presented in Figures 3 and 4.

\section{RESULTS}

Curves of downhole variations of aragonite, calcite, magnesian calcite, dolomite, and quartz are the major result of this study. (Figs. 3 and 4). These curves, especially the one for aragonite content, are the stratigraphic basis for observations about sedimentation rates and distribution of turbidites with respect to late Cenozoic sea-level fluctuations.

\section{Aragonite Stratigraphy}

The upper part of the aragonite curve (Fig. 5) closely resembles those curves obtained from other parts of the Bahamas by Kier and Pilkey (1971), Droxler et al. (1983), Droxler (1984), and Boardman et al. (1986). The asymmetric, 100,000-yr cycles are particularly obvious. Each of the top three cycles can be correlated with Core GS:7705-34 of Droxler et al. (1983). This correlation, along with the nannostratigraphic datums, links the oxygen-isotope stratigraphy, corroborating the conclusion of Droxler et al. (1983) that the aragonite concentration in the Bahamian periplatform sediments can be used as a proxy indicator of the oxygen-isotope curve.

Comparison of the aragonite curve with the isotope curve of Shackleton et al. (1984) from the North Atlantic yields a rather convincing correlation down to isotope Stage 24 with three nannostratigraphic markers as check points. Important additional constraints are provided by correlation with nearby Site 633 (Droxler et al., this volume), which is located on a bypass slope and nearly devoid of turbidites. The stratigraphy of Site 633 can be used as a standard because it includes the oxygen-isotope 


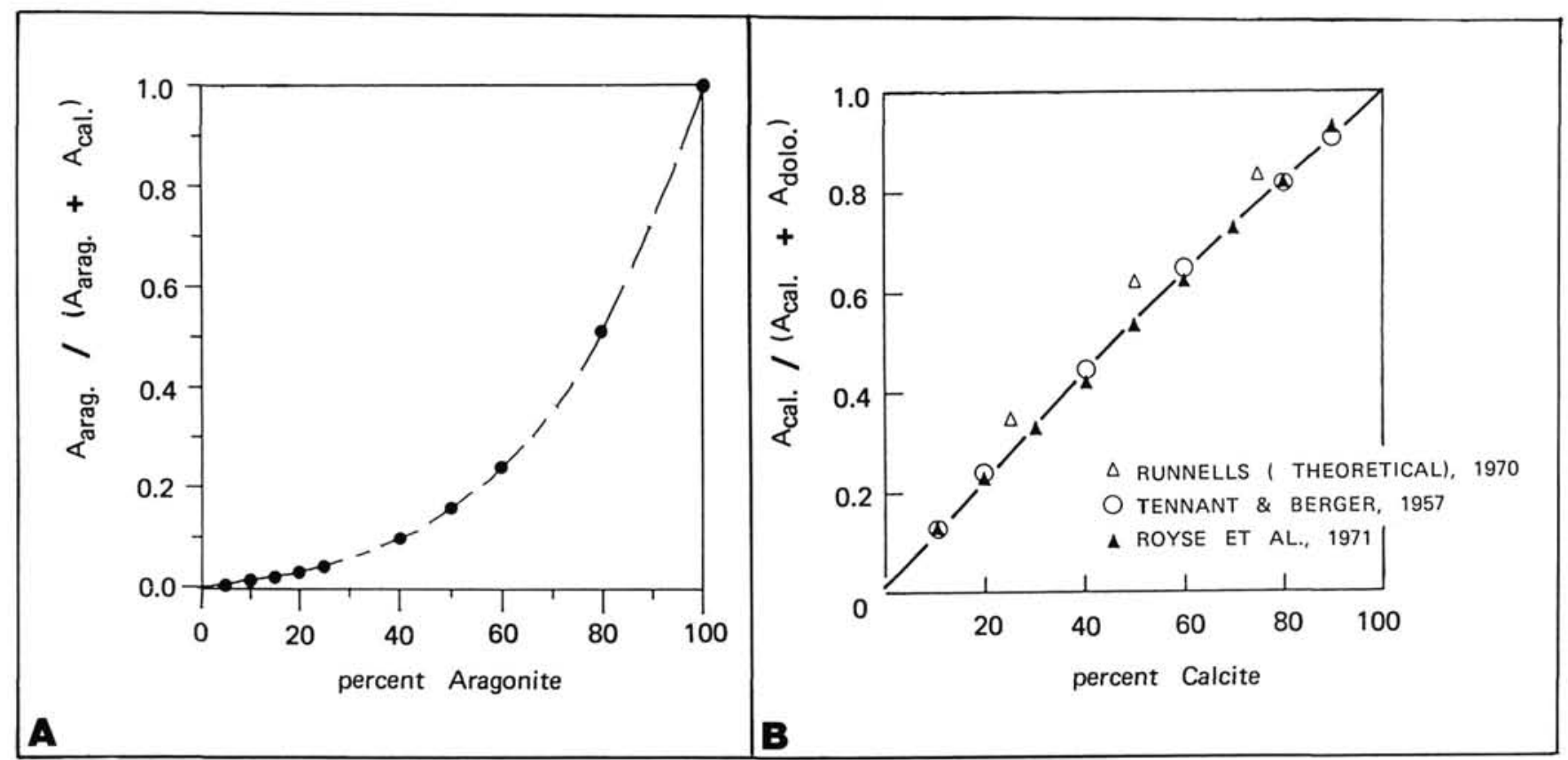

Figure 2. Calibration curves for quantitative X-ray diffraction analysis. A. Aragonite/calcite ratio, based on analysis in this study. B. Dolomite/ calcite ratio (after Milliman, 1974). A-arag., A-cal., A-dolo. = peak areas of aragonite, calcite, and dolomite, respectively. A-cal. includes all calcites regardless of magnesian content.

curve and several magnetic reversals in addition to the aragonite and biostratigraphic data used here. Two clay bands (at 11.0 and $21.1 \mathrm{mbsf}$ in Hole 632A) and the occurrence of magnesian calcite maxima (at 14.5-16.5 mbsf and 25.5-32.5 mbsf in Hole 632A) provide additional links between the two sites.

Below Stage 24 (33.5 mbsf), the aragonite stratigraphy becomes fragmentary owing to incomplete recovery, thick turbidite and debris-flow intervals, and downhole contamination (Core 101-632A-5H). However, the overall shape of the curve indicates the absence of asymmetric 100,000-yr cycles and smaller amplitudes of the aragonite variations. Identification of nannofossil zones NN16, NN17, and NN18 (A. Kleijne, pers. commun.) in the interval at 45.5-52 mbsf allows us to compare these zones with a segment of the late Pliocene isotope curve (Shackleton et al., 1984). The similarity of aragonite and oxygen-isotope variations at this level is obvious (see Fig. 6). The amplitude of the aragonite variation decreases, and mean aragonite content increases, compared to the top $33.5 \mathrm{~m}$. This change in the overall shape of the curve also may be observed in the global oxygen-isotope curve (Shackleton et al., 1984).

\section{Calcite, Magnesian Calcite, Dolomite, and Quartz}

Distribution of these minerals reveals close similarities with the cores of Droxler (1984), suggesting that the composition of the most recent periplatform sediment is representative for a large part of the Quaternary.

Calcite is inversely correlated with aragonite (Figs. 3 and 4) and reaches its highest concentrations in the glacial intervals.

Magnesian calcite shows a maximum in the shallow subsurface (1.0 to $2.5 \mathrm{mbsf}$ ), then decreases downhole with some minor maxima at 14.5-16.5 mbsf and 25.5-32.5 mbsf (Fig. 3). This pattern is consistent with a partly diagenetic origin of this mineral (Droxler et al., 1983), although no direct observations were made.

Dolomite occurs frequently in the top $54.7 \mathrm{~m}$ of Hole $632 \mathrm{~A}$, but at low percentages (maximum of $2.6 \%$ of total carbonate). In Samples 101-632A-2H-3, $111 \mathrm{~cm}$, and -632A-3H-2, $142 \mathrm{~cm}$, dolomite occurs with abundant terrigenous material, suggesting a detrital origin. Below 54.7 mbsf dolomite occurs in every sam- ple recovered. Some of these are highly indurated, suggesting dolomite formation in the course of shallow burial diagenesis (see inorganic geochemistry discussions in Austin, Schlager, et al., 1986).

Quartz follows the same trend as calcite, with highest concentrations in the glacial intervals (Fig. 3). This trend becomes increasingly obvious toward the top of Hole $632 \mathrm{~A}$, suggesting a relatively greater terrigeneous influence. Two quartz maxima occur; the maxima forementioned also show an increase in dolomite input. These maxima occur at glacial/interglacial transitions.

\section{SEDIMENTATION RATES AND TURBIDITE DISTRIBUTION}

Glacial and interglacial sedimentation rates were calculated from the isotope stages in Figure 3, using ages for stage boundaries 1-19, assigned by Von Grafenstein (1982) (Fig. 7D). Interglacial bulk-sedimentation rates are 1.1 to 8.8 (average 3.9 ) times higher than those of the adjacent glacial intervals (Fig. 7A). Also apparent is an upward decrease in bulk-sedimentation rates from Stage 19 to Stage 5, followed by an increase in Stages 2-4 and Stage 1. We attribute this long-term decrease to the local setting of the site in a channel fill, and the increase in the topmost section to a lack of compaction.

Figure 7B displays turbidite accumulation rates calculated for glacial and interglacial isotope stages. Our statistics are based on shipboard descriptions and interpretation of cores and core photographs (Austin, Schlager, et al., 1986). We counted only large, easily identifiable turbidites. Turbidites underlain by glacial deposits and overlain by interglacial ones (or vice versa) were divided evenly between the two isotope stages. As with bulksedimentation rates, turbidites also show a glacial/interglacial rhythm, with higher contributions during interglacials (Fig. 7B). The upward decrease in rates is even more pronounced than with bulk-sedimentation rates.

Periplatform-ooze sedimentation rates show a greater variance than bulk-sedimentation rates (Fig. 7C and 7D). Intergla$\mathrm{cial} /$ glacial ratios of sedimentation rates vary from 0.85 for isotope Stages 9 and 10 to 8.3 for isotope Stages 5 and 6 . The in- 


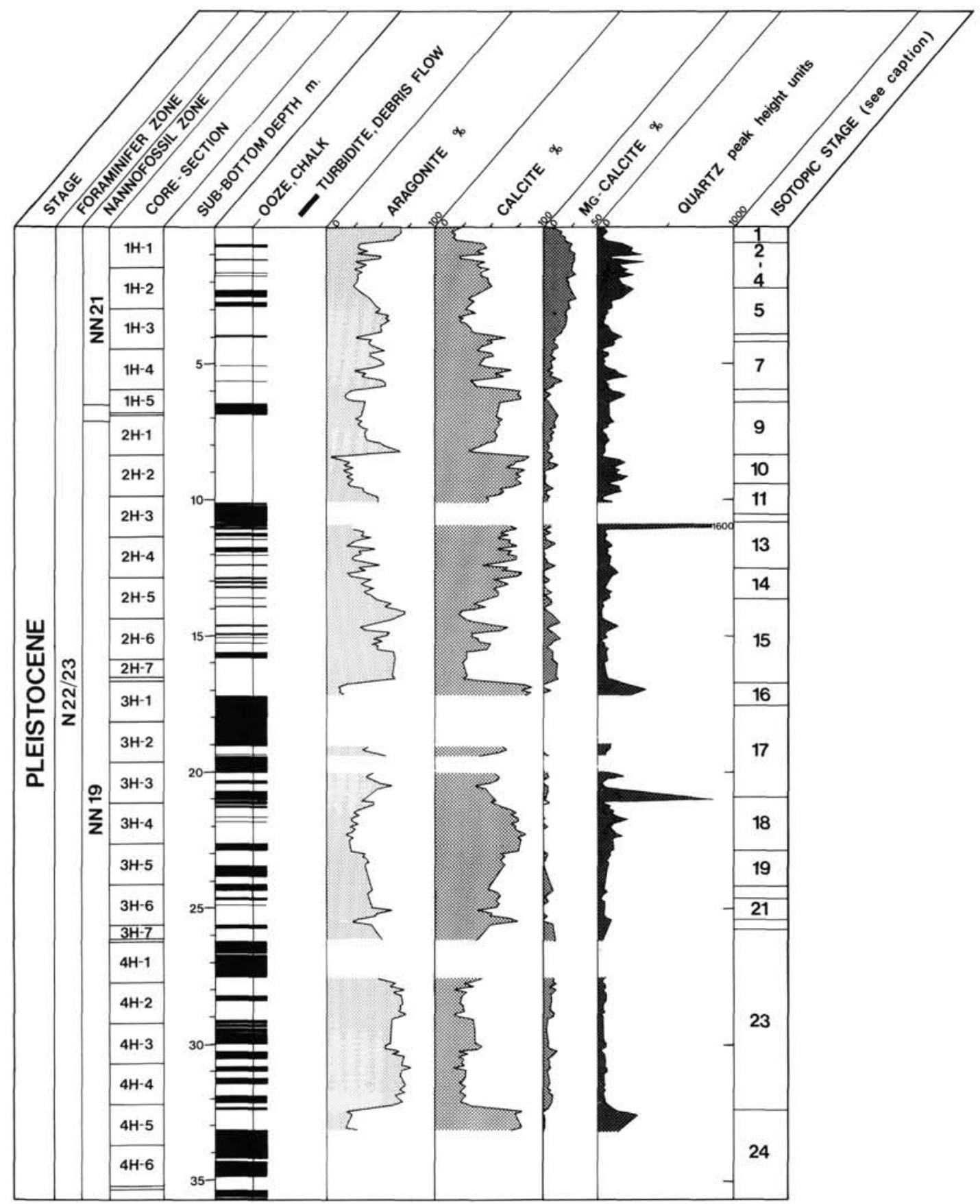

Figure 3. Depth variations of lithology (turbidite or debris flow; chalk or ooze), aragonite content, calcite content, magnesian calcite content, and quartz occurrence for the upper $35.9 \mathrm{~m}$ of Hole $632 \mathrm{~A}$. See text for analytical details. The oxygen-isotope stages assigned by comparison of the aragonite curve with the isotope curve of Shackleton et al. (1984) from the North Atlantic. Biostratigraphy after Austin, Schlager, et al. (1986).

verse relationship for isotope Stages 9 and 10 illustrates the importance of the turbidite contribution to bulk-sedimentation rates. When one compares bulk-sedimentation rates, the rate for isotope Stage 9 is 1.1 times greater than the rate for isotope Stage 10 (the normal pattern). Erosion by turbidites in the top part of this interglacial stage may be responsible for this deviation. Figure 5 clearly shows that the top part of the stage is missing.

In Figure 7D sedimentation rates for the glacial and interglacial isotope stages are plotted separately to distinguish turbidite input from periplatform ooze input in the glacial and intergla- cial intervals. Clearly, turbidites contribute more in interglacial sediments and also enhance the increased periplatform-ooze input signal. Another remarkable feature is the alternation of high and low rates among glacial periods. The cause of this fluctuation is unknown.

\section{DISCUSSION AND CONCLUSIONS}

This study is the first documentation of sedimentation on a Bahamian basin floor that extends beyond the last two glacial cycles. The upper $34 \mathrm{~m}$ of Site 632 was cored using the hydraulic piston corer; recovery was nearly $100 \%$. The top cores of Hole 


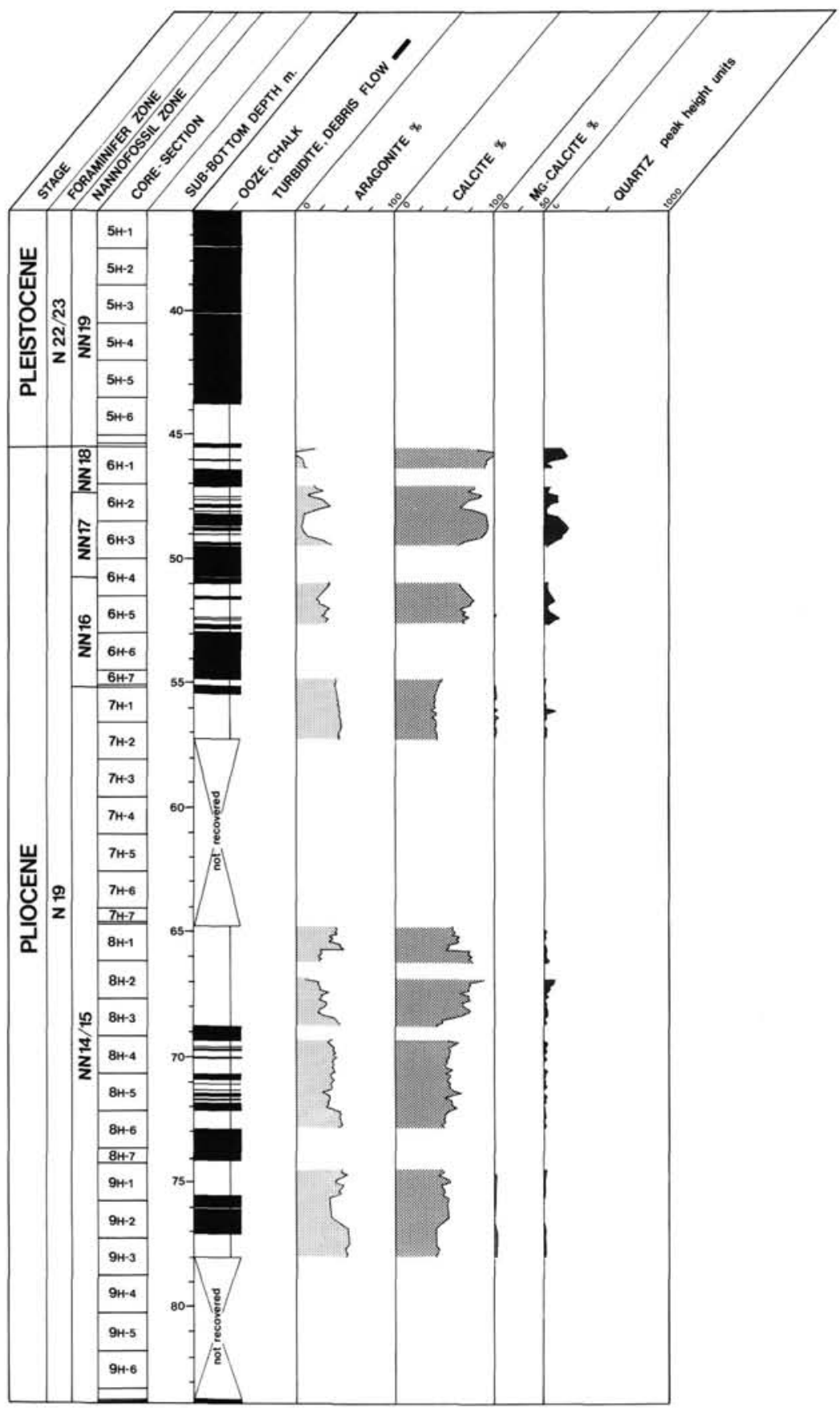

Figure 4. Depth variations of lithology (turbidite or debris flow; chalk or ooze), aragonite content, calcite content, magnesian calcite content, and quartz occurrence for the lower part of Hole 632A (35.9 mbsf to $83.8 \mathrm{mbsf}$ ). See text for analytical details. Biostratigraphy after Austin, Schlager, et al. (1986).

632A can be compared directly with the database of Droxler and Schlager (1985), which involved 8- to 13-m-long piston cores. Comparing the section in both the cores of Droxler and Schlager (1985) and this study indicates basic similarities, as well as important differences. The overall setting in a bathyal basin surrounded by active carbonate platforms is similar; the sediment facies is almost identical: periplatform ooze and mud with intercalated graded beds of carbonate sand and silt, which we interpreted as turbidites. Differences concern sedimentation rates. Those at Site 632 are lower than average for the Tongue of the Ocean. Depth to the base of the Sangamon interglacial is 9.6,
$7.7,6.9,4.8$, and $3.2 \mathrm{mbsf}$, respectively, in the cores of Droxler and Schlager (1985); at Site 632 depth to the base of the same interglacial interval is $3.8 \mathrm{mbsf}$; most of the older cycles are even thinner at about $2.5 \mathrm{mbsf}$. These lower sedimentation rates at Site 632 can be explained by differences in hinterland and by topography at the site. The platform rim of southern Tongue of the Ocean is broader and more complete than that of Exuma Sound. Furthermore, Site 632 lies near the exit of Exuma Sound where an axial valley cuts into the flat basin floor, indicating episodic erosion by turbidity currents that accelerate as they flow down into Exuma Canyon. Very thin records of Stages 6, 8, 11 


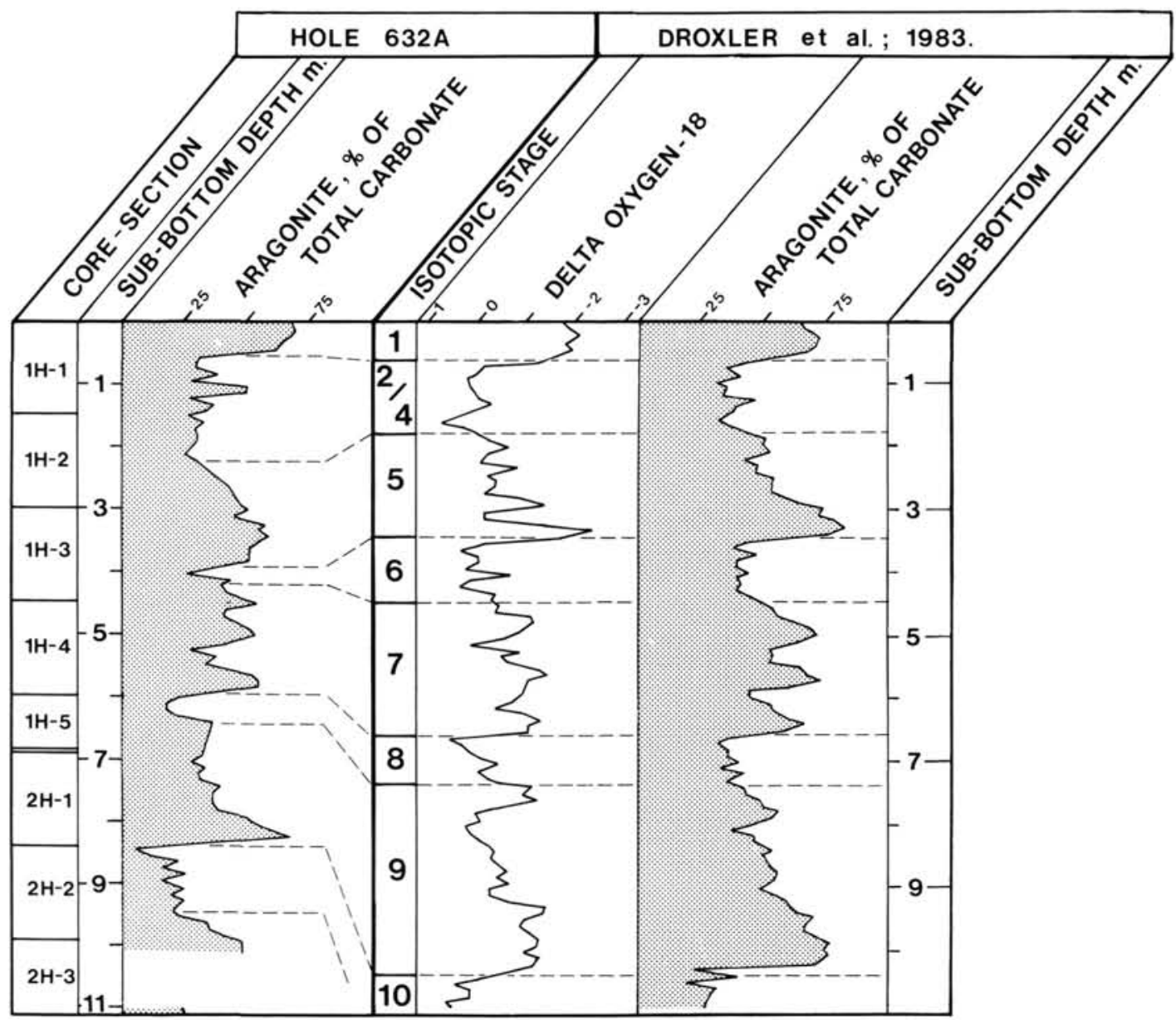

Figure 5. Correlation of the aragonite curve for the top 10 isotope stages of Hole 632A with the standard core, GS:7705-34 of Droxler et al. (1983).

and 12, 16, and the thinned record of Stage 9 probably are caused by these pulses of erosion. The record at Site 632 is similar, yet less perfect, than that of the southern part of the Tongue of the Ocean.

Despite the minor imperfections of the record, Site 632 displays the effects of high-stand shedding much like the cores in Tongue of the Ocean, but effects that extend back to the middle Pleistocene. Bulk- and periplatform-ooze sedimentation rates oscillate regularly between interglacial highs and glacial lows (Fig. 7) down to isotope Stage 19. We did not calculate rates for Stages 20 through 24 because we did not have a precise time scale for the isotope stages. We used the age of the stage boundaries for the Brunhes epoch proposed by Von Grafenstein (1982). The higher periplatform-ooze sedimentation rate for isotope Stage 9, compared with the rate for isotope Stage 10 (Fig. 7C), we attribute to erosion of the top part of the deposited periplatform ooze by turbidity currents, which occur at the transition from Stage 9 to Stage 8 (Fig. 3). When one compares the aragonite curve for Stage 9 of Droxler et al. (1983) with the curve for the same interval in Hole 632A (Fig. 5), the truncation of Stage 9 in Hole $632 \mathrm{~A}$ is obvious.

Turbidites occur in both high- and low-stand deposits yet are clearly more abundant and contribute more sediment during interglacial high stands of sea level (Fig. 7B and 7D). However, the difference between glacials and interglacials varies more and is smaller on average than in Tongue of the Ocean. We attribute this partly to the lower sedimentation rates in Exuma Sound. The cores of Droxler and Schlager (1985) indicate that the higher turbidite frequency during high stands of sea level is most pronounced in those cores having the highest sedimentation rates and largest numbers of turbidites (compare Core 16 with Core 13 in Droxler and Schlager, 1985; see their Fig. 1). In addition, we must base our distribution study on shipboard core descriptions (which logged only the more conspicuous turbidites because of severe time constraints and no X-radiographs).

Superimposed on the glacial/interglacial rhythm we note an upward decrease in turbidite contribution and, to a lesser extent, in the bulk-sedimentation rates (Fig. 7B and 7D). The extremely high rate in Stage 17 is caused by a single flow, possibly triggered by an extraneous event, such as a rare earthquake. This upward-thinning trend may depend on the development of the axial valley of Exuma Sound. Seismic stratigraphy indicates that the upper $95 \mathrm{~m}$ at Site 632 represents the filling of a channel, probably a precursor of the axial valley that currently lies a few kilometers north of the site (Austin, Schlager, et al., 1986). As the old valley filled up, sedimentation rates and turbidite thickness decreased because more turbidity currents were captured by the deepening new valley and were funneled into the nearby Exuma Canyon.

Whereas turbidite contribution can be satisfactorily explained as input variations in an upward-fining valley fill, changes in composition and sedimentation rates of periplatform ooze are another matter. The downhole decrease of magnesian calcite and the appearance of dolomite a few meters below the seafloor is best explained by shallow burial diagenesis, that is, dissolution of magnesian calcite and precipitation of dolomite in the 


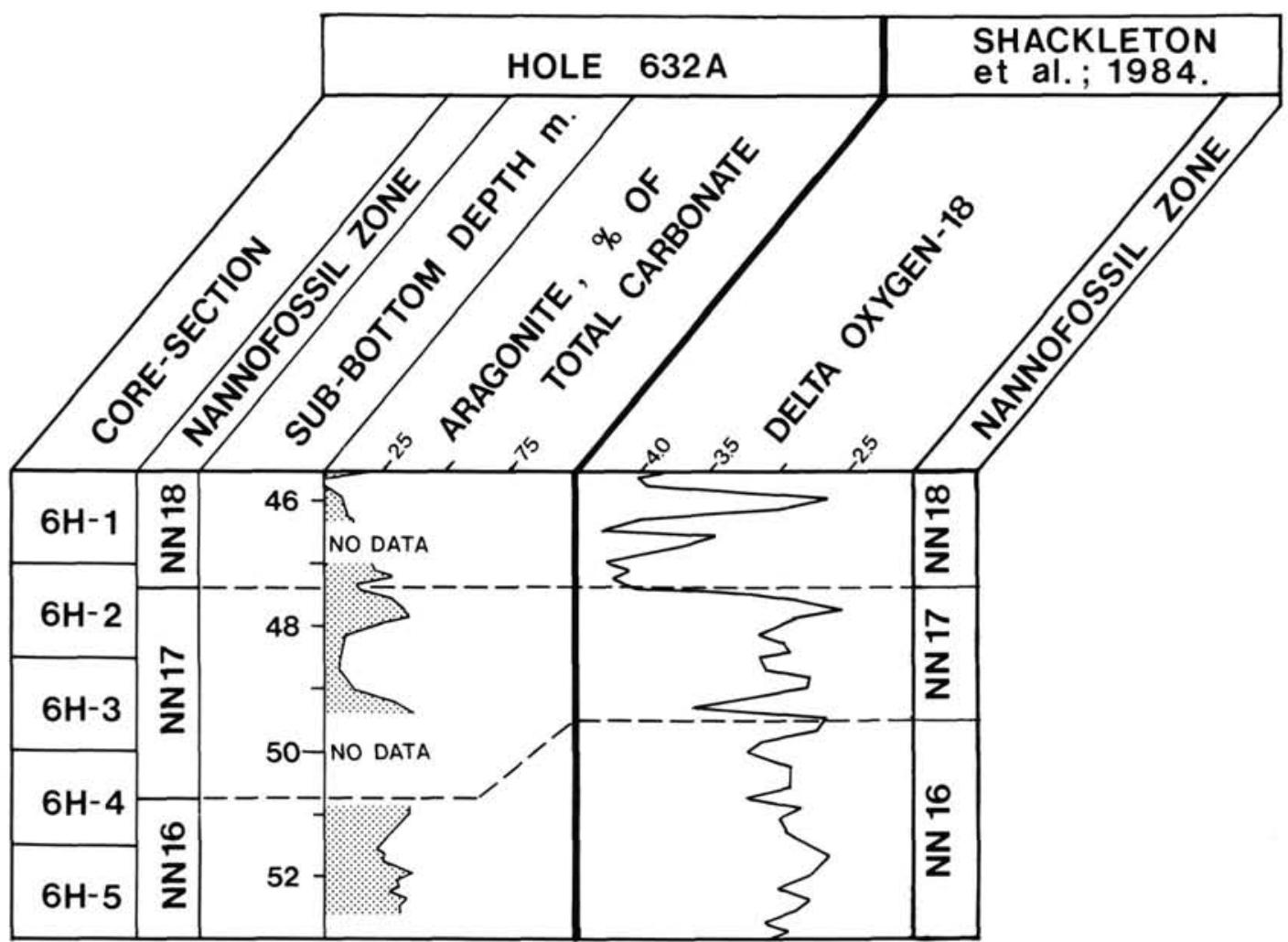

Figure 6. Comparison of the aragonite curve of part of the Late Pliocene interval of Hole 632A with the coeval part of the oxygen-isotope curve from the central North Atlantic (Shackleton et al., 1984). Dashed lines in figure represent boundaries of nannofossil zones that could be correlated.

top $20 \mathrm{~m}$ and dolomite formation below $54.7 \mathrm{mbsf}$ induced by degradation of organic matter (Swart and Guzikowski, this volume). The variation of aragonite content is closely coupled with the oxygen-isotope curve; it is, therefore, a primary signal, not a diagenetic one. The detailed match between aragonite content and oxygen-isotope ratios shown in Figures 5 and 6 is not easily explained by input variations related to exposure and flooding of the banks (Boardman et al., 1984). The match extends to small variations during low stands when the entire bank tops must have been exposed. The covariation also includes the change from a 100,000-yr cycle in the late Pleistocene to a lower amplitude, shorter rhythm in the early Pleistocene and Pliocene (Figs. 3 and 4; Shackleton et al., 1984). The aragonite variations seem to be much more finely tuned to the ocean-atmosphere system than might be accomplished by simple flooding and exposure of the banks in response to the $100,000-y r$, sea-level cycles. In line with Droxler et al. (1983), we suggest that fluctuations of carbonate dissolution levels in the ocean provide this link. During glacial intervals, dissolution is more intensive and dissolution levels rise. Selective removal of aragonite during glacial low stands of sea level thus enhances and modifies the input variations in aragonite, which also causes an aragonite minimum during low stands of sea level.

In summary, turbidite data at Site 632 indicate significant variations of sediment input from banks during glacial/interglacial cycles of sea level. In contrast, variations of periplatform ooze point to carbonate dissolution as a significant modifier of this input signal (Fig. 7D).

\section{ACKNOWLEDGMENTS}

We thank the Dutch Institute for Sea Research (NIOZ) for the use of their X-ray diffraction system, S. van der Gaast for introducing J. R. to the secrets of this system, and A. Vaars for his technical assistance. A. Sprenger wrote the main part of the computer program for the quantita- tive X-ray analysis. A. Kleyne provided part of the nannofossil identification and C. H. Bruce, W. W. Sager, and D. K. Watkins shared important stratigraphic results of Site 633 with us. We thank the ODP Core Repository at Lamont-Doherty Geological Observatory, particularly R. Hayman, for assistance with sampling. We also thank H. Moonen and P. Willekes for help with sample preparation, and $\mathrm{H}$. Bosscher for his role as midwife in the final stages of labor of this paper. We also thank James A. Austin, Jr., David C. Twichell, Jr., and Amanda Palmer for reviewing this paper.

\section{REFERENCES}

Austin, J. A., Jr., Schlager, W., et al., 1986. Proc. ODP, Init. Repts., 101: College Station, TX (Ocean Drilling Program).

Boardman, M. R., Neumann, A. C., Baker, P. A., Dulin, L. A., Kenter, R. J., Hunter, G. E., and Kiefer, K. B., 1986. Banktop responses to Quaternary fluctuations in sea level recorded in periplatform sediments. Geology, 14:28-31.

Droxler, A. W., 1984. Late Quaternary glacial cycles in the Bahamian deep basins and in the adjacent Atlantic Ocean [Ph.D. dissert.]. Univ. Miami, Coral Gables, FL.

Droxler, A. W., and Schlager, W., 1985. Glacial versus interglacial sedimentation rates and turbidity frequency in the Bahamas. Geology, 13:799-802.

Droxler, A. W., Schlager, W., and Whallon, C. C., 1983. Quaternary aragonite cycles and oxygen-isotope record in Bahamian carbonate ooze. Geology, 11:235-239.

Kier, J. S., and Pilkey, O. H., 1971. The influence of sea level changes on sediment carbonate mineralogy, Tongue of the Ocean, Bahamas. Mar. Geol., 11:189-200.

Lynts, G. W., Judd, J. B., and Stehman, C. F., 1973. Late Pleistocene history of Tongue of the Ocean, Bahamas. Geol. Soc. Am. Bull., 84: 2665-2684.

Milliman, J. D., 1974. Marine Carbonates: Berlin-Heidelberg (SpringerVerlag).

Mullins, H. T., 1983. Comment on "Eustatic control of turbidites and winnowed turbidites." Geology, 11:57-58.

Neumann, A. C., 1965. Processes of recent carbonate sedimentation in Harrington Sound, Bermuda. Bull. Mar. Sci., 15:987-1035. 
Royse, C. F., Jr., Wadell, J. S., and Petersen, L. E., 1971. X-ray determination of calcite-dolomite: an evaluation. J. Sediment. Petrol., 41:483-488.

Runnells, D. D., 1970. Errors in X-ray analysis of carbonates due to solid-solution variation in composition of component minerals. $J$. Sediment. Petrol., 40:1158-1166.

Schlager, W., and James, N. P., 1978. Low-magnesian calcite limestones forming at the deep-sea floor, Tongue of the Ocean, Bahamas. Sedimentology, 25:675-702.

Shackleton, N. J., Backman, J., Zimmerman, H., Kent, D. V., Hall, M. A., Roberts, D. G., Schnitker, D., Baldauf, J. G., Desprairies, A., Homrighausen, R., Huddlestun, P., Keene, J. B., Kaltenback, A. J., Krumsiek, K.A.O., Morton, A. C., and Westberg-Smith, J.,
1984. Oxygen isotope calibration of the onset of ice-rafting and the history of glaciation in the North Atlantic region. Nature, 307:620623.

Tennant, C. B., and Berger, R. W., 1957. X-ray determination of dolomite-calcite ratio of a carbonate rock. Am. Mineral., 42:23-29.

Von Grafenstein, R., 1982. 750.000 Jahre klimageschichte und PaläoOzeanographie en einem Tiefseekern vom Sierra Leone Rucken (Äquatorialer Ostatlantik) [M.Sc. thesis]. Christian Albrechts Universität, Kiel, Germany.

Date of initial receipt: 5 January 1987

Date of acceptance: 14 July 1987

Ms 101B-137
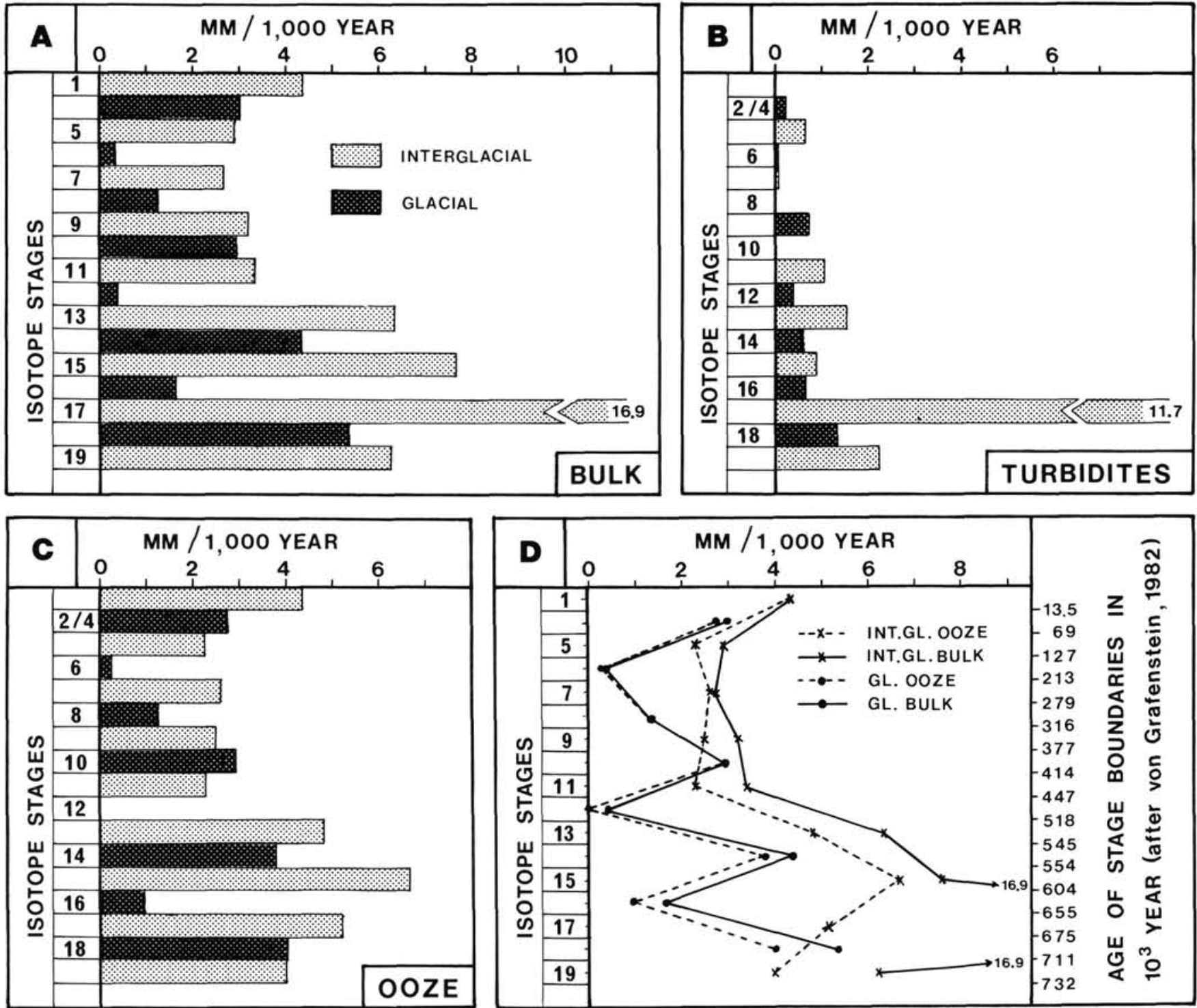

Figure 7. Sedimentation rates of Hole 632A for isotope Stages 1 through 19. (A) bulk sedimentation rates, (B) turbidite accumulation rates, (C) periplatform ooze sedimentation rates, and (D) comparison of (A) with (C). Int.G1. = interglacial; Gl. = glacial. Glacial and interglacial isotope stages are connected separately. Higher rates during interglacial stages are attributed to increased input from the banks and reduced dissolution in the deep sea. Long-term decrease of rates probably is related to the gradual filling of the submarine valley where Site 632 is located. Note the high turbidite contribution during interglacial stages, particularly obvious in (D). 